\title{
THE EFFECT OF GUIDED IMAGERY AND HEALTH EDUCATION ON HEART FAILURE PATIENT ANXIETY DURING THE COVID-19 PANDEMIC AT HOSPITAL X
}

\author{
Tommy J F Wowor, Ni Luh Widani, Willhelmus Hary Soesilo \\ Prodi Keperawatan Program Magister STIK Sint Carolus Jakarta \\ tommywowor@civitas.unas.ac.id \\ DOI: http://doi.org/10.29080/ihsp.v5i2.594
}

Received : Agustus 2021, Accepted : Agustus 2021, Published : September 2021

\begin{tabular}{ll}
\hline Keywords & Abstract \\
\hline Anxiety; & There are conditions that increase an individual's risk of having a poor \\
COVID-19; & health Education; \\
heart failure; & condition can cause anxiety in heart failure patients and reduce the body's \\
guided imagery & resistance. This study aims to identify the effect of guided imagery and health \\
education on the anxiety of heart failure patients during the COVID 19 pandemic. \\
The study used a Quasi Experiment. The number of samples was 62 respondents, \\
given guided imagery relaxation and health education through booklets for 14 \\
days. Statistical tests used Wilcoxon test. The results showed that the level of \\
anxiety before the intervention 61.3\% moderate anxiety level and after the \\
intervention 83.9\% were not anxious. There was a significant effect between \\
guided imagery and health education with anxiety levels (0.000). In conclusion, \\
guided imagery relaxation and health education have an effect on decreasing the \\
anxiety level of heart failure patients. This study recommends the need for further \\
research on other therapies as nurse interventions in heart failure nursing care.
\end{tabular}

\section{Introduction}

Cardiovascular diseases are a global threat and the leading cause death in the world. The data of WHO reveals that in 2019, more than 17 million deaths in the world are caused by cardiovascular diseases (1). As a comparison, HIV/AIDS, malaria and TBC altogether make up for 3 million deaths. Based on the Basic Health Research (2), the incidence rate of cardiovascular disease is steadily increasing every year. At least 15 out of 1000 individuals, or around 2,784,064 individuals in Indonesia suffer from heart diseases (3).

Heart failures are a group of complex symptoms where a patient presents with: heart failure symptoms (typical shortness of breath when resting or during activity with or without fatigue); fluid retention symptoms (lung congestion or edema in foot or ankle); objective signs of structural impairment of heart functions when resting (4).

There are several conditions that can increase risk of developing and having poor prognosis when infected with COVID-19, including as old age and chronic diseases such as diabetes mellitus, hypertension, heart disease, respiratory disease, cancer, and etc. In addition, smoking habit can also increase risk of infection (5). A patient with heart failure or other heart disease may have increased susceptibility against the infection of the COVID-19 virus and be associated with worse outcomes of the virus (6). A patient with heart failure during the pandemic is likely to feel increased anxiety. Anxiety can range from mild to severe anxiety. Short-term psychotherapy for heart failure outpatient shows an effect on depression and quality of life without increasing anxiety (7).

There are several ways to treat anxiety in a heart failure patient. One is through guided imagery. This relaxation technique can be implemented as a clinical or non-clinical method, both aiming to reduce stress and induce relaxation, improve performance and behavior as well as obtain words and images on the 
subconscious(8). It uses a person's imaginations with guided imagery to reduce stress. Guided imagery is categorized in mind-body medicine therapy by combining guided imagery with mental meditation as a cross-model adaptation. It could be performed relatively easily by a patient since a therapist guides imagination technique therapy; thus, errors and mistakes can be kept at minimal during the implementation. In addition, guided imagery also assigns control to the patient so as to provide physical and mental comfort to the patient (9).

In addition to the guided imagery technique, the provision of health education can also reduce anxiety levels in a heart failure patient. Several journals recommend the importance of stress management on cardiac rehabilitation patients to decress the psychological stress and emotional disruption effects such as anxiety and depression (5). In addition, the results of other studies found that a negative perception of the prognosis of a disease is one of the factors that can cause anxiety in heart failure patients.(10).

Hospital X is one of hospitals designated as a treatment center for heart failure patients. Hospital X is among the hospitals located in an Orange Zone from july until august period in the province of West Java (COVID-19 Cluster, 2020). Data obtained from Hospital X's database show that there are 516 patients with heart failure diagnoses in the past three months from October to December 2020. The fear of not being able to carry out routine treatment or control, worrying about being infected with the COVID-19 virus and the possible fatal impact if a patient with congestive heart failure is infected with COVID-19 result in anxiety and an increase in blood pressure in patients with congestive heart failure. This is evidenced by the drastic decrease in the number of hospital visits by heart failure patients in the 3 months before the start of the pandemic, from as many as 582 patients to only 42 patients during that time. Moreover, health education provided by the hospital so far is limited to patient complaints, making it unstructured and noncomprehensive. Therefore, the researchers are intrigued to conduct a study title The Effect of Guided Imagery and Health Education on Health Failure Patient Anxiety During the COVID-19 Pandemic at Hospital $\mathrm{X}$.

\section{Methods}

The study used quasi experimental design: one group pretest-posttest without control group. The population in this study was the entire heart failure patients at Hospital X. There were 126 heart failure patients in the last 3 months. Data were taken following the approval of the hospital and Health Research Ethics Committee with No. 036/KPEKSTIKSC/IV/2021. Samples were taken using purposive random sampling. 62 respondents were obtained for this study. Respondents were subjected to interventions namely Guided Imagery and Health Education for 14 days. The data were analyzed using univariate descriptive analysis and Wilcoxon bivariate test.

\section{Results}

Table 1. Distribution of Genders of Heart Failure Patients Subjected to Guided Imagery and Health Education

\begin{tabular}{lccc} 
& Gender & Frequency & Percentage \\
\hline Male & 36 & 58.1 \\
\hline Female & 26 & 41.9 \\
\hline Total & $\mathbf{6 2}$ & $\mathbf{1 0 0}$ \\
\hline
\end{tabular}

Based on Table 1 above, most of the respondents are male (58.1\%). In this case Black\& Hawks (2014), male has higher risk to experience heart attack on young age, while in female, the risk increases when entering the menopause(11).

Table 2. Distribution of Age of Heart Failure Patients Subjected to Guided Imagery and Health Education

\begin{tabular}{ccccc}
\hline Variable & $\mathrm{N}$ & Mean & SD & Min-Max \\
\hline Age & 62 & 50.66 & 8.388 & $35-66$
\end{tabular}

Table 2 above presents the description of the age range of the respondents, in which the age range of the heart failure patients was 36-66 years old. In this case, the age affects the risk of suffering from cardiovascular disease because it causes changes on heart and blood vessel. 
Table 3. Distribution of Anxiety Levels of Heart Failure Patients Before and After Guided Imagery and Health Education

\begin{tabular}{lcccc}
\hline \multirow{2}{*}{ Anxiety Levels } & \multicolumn{2}{c}{ Pre } & \multicolumn{2}{c}{ Post } \\
\cline { 2 - 5 } & F & $\mathbf{\%}$ & F & \% \\
\hline No Anxiety & 4 & 6.5 & 52 & 83.9 \\
Mild Anxiety & 20 & 32.3 & 8 & 12.9 \\
Moderate Anxiety & 38 & 61.3 & 2 & 3.2 \\
Severe Anxiety & 0 & 0 & 0 & 0 \\
Very Severe Anxiety & 0 & 0 & 0 & 0 \\
\hline Total & 62 & 100 & 62 & 100 \\
\hline
\end{tabular}

Furthermore, Table 3 above shows the distribution of anxiety level of the respondents before and after intervention was provided. On data distribution before intervention, it was obtained that the majority of heart failure patients (61.2\%) experienced anxiety during this pandemic. Data on the post-intervention further obtained that there was decrease on the anxiety level distribution. In addition, it was also shows that $83.9 \%$ respondents have not experienced anxiety when the intervention was provided.

Table 4. Analysis of Differences in Anxiety Levels Before and After the Interventions with Guided Imagery and Health Education

\begin{tabular}{lccccccc}
\hline Anxiety Level & $\begin{array}{c}\text { Pre- } \\
\text { test }\end{array}$ & $\mathbf{\%}$ & $\begin{array}{c}\text { Post- } \\
\text { test }\end{array}$ & $\mathbf{\%}$ & $\begin{array}{c}\text { Performance } \\
\text { difference }\end{array}$ & $\begin{array}{c}\text { \% } \\
\text { Selisih }\end{array}$ & Pvalue \\
\hline Not anxious & 4 & 6,45 & 52 & 83,87 & 48 & 92,30 & 0,000 \\
Mild anxiety & 30 & 48,39 & 8 & 12,90 & -22 & -275 & \\
Medium anxiety & 28 & 45,16 & 2 & 3,23 & -26 & 1300 & \\
\hline
\end{tabular}

Based on the results of bivariate test and Wilcoxon, the p-value obtained was 0.000 . This means that there was statistical and significant difference on the heart failure patients' anxiety level during COVID-19 pandemic before and after guided imagery intervention and health educational intervention were provided.

\section{Discussion}

In Table 1, we can see that the majority (58.1\%) of the respondents are male. Men have a higher risk of having a heart attack at a young age and in women, this risk increases as they reach the menopause. Studies conducted in United States and Europe show that anxiety is common among men with heart failure (12). A study shows that $56.4 \%$ of his total respondents are male and have heart failure due to unhealthy lifestyle, smoking habit and alcohol consumption. Smoking is associated with heart diseases due to its nicotine and tar contents (13).

Table 2 shows the distribution of respondents' anxiety levels before and after the interventions. Before the interventions, the majority (61.2\%) of the heart failure patients report moderate anxiety during the pandemic. Post interventions, a decrease in the distribution of anxiety levels is observed $83.9 \%$ of the respondents no longer report anxiety. Psychological issues also emerged on heart failure patients. Patients who suffer from heart failure commonly experience anxiety because they find it difficult to maintain adequate oxygenation so that it emerges the feeling of anxiety and difficulty in breathing (11). Such predisposition factor as what obtained from the interview results with the respondents that they are afraid of their weak condition, their worsen disease manifestation and prognosis, the future medication, the length of the therapy, the high rate of hospitalization, cost incurred, length of treatment as well as thinking of death (14).

Cancellation and postponement of scheduled doctor visits, investigation, procedure, prescription and monitoring service are thought to be sources of anxiety. A study by (15) demonstrate significantly higher levels of anxiety regarding the COVID-19 pandemic compared to anxiety regarding heart failure itself $(\mathrm{p}<0.001)$. In addition, it was also revealed that $65 \%$ of 1050 respondents report cancellation of doctor visits due to COVID-19 lockdown period, various types of heart examinations and interventions such as pacemaker insertion. Nearly one third $(32 \%)$ of heart failure patients surveyed in the study report that they were reluctant to come to the hospital, another $25 \%$ stated that they would only come to the hospital if there is no other alternative and $7 \%$ say that they will not come to the hospital at all in this COVID-19 pandemic (15).

Table 3 shows that the age range of the heart failure patients is 36-66 years old. Age significantly influences the risk of developing a cardiovascular disease since it brings changes to the heart and blood vessels. It is one of the risk factors for cardiovascular diseases that might result in heart failure because old age can increase the risk of plaque accumulating on the blood vessel wall and blocking blood (16). This study is also supported by research conducted at the Internal Medicine Polyclinic of the MH Palembang Hospital for the period of 2012 a significant relationship between age $>55$ years and smoking with the incidence of CHD. (17)From the above explanation, it can be concluded that age contributes to the 
occurrence of heart disease, which is increasingly common in elderly. Aging process causes the arteries and aorta to lose their elasticity and become rigid and crooked which impair blood perfusion to the heart or through the body, also known as atherosclerosis.

Based on the bivariate analysis using Wilcoxon as presented in Table 4, it indicates that the p-value obtained was 0.000 . This means that there was significant and statistical difference on the heart failure patients' anxiety level during COVID-19 pandemic, before and after the guided imagery therapy and health educational interventions were provided. Guided imaginary relaxation was employed to decrease the anxiety level of the patients by imagining a condition or a series of happy experiences with guidance and involving senses (18). Guided imagery aims to produce and reach optimal condition which was used to shift the attention from desolate sensation (19). This research is in accordance with the previous research carried out by (6)where a-one-week relaxation using guided imagery decreased stress symptoms, insomnia, depression, physical symptoms, and psychological pressure significantly.

The effectiveness of the guided imagery relaxation therapy on decreasing the anxiety levels of heart failure patients in this study is also further reinforced by the addition of another intervention namely health education. The health education is provided in the form of a booklet containing knowledge about heart failure, anxiety and COVID 19. Health education for patients has been found to be one of the most essential treatment programs based on the identification and control of patient health criteria. (20)showing that the anxiety of the case group is lower compared to the control group $(\mathrm{P}<0.0001)$ after being given a health education program (21). Similar result is also observed by Sulistyowati et al. (2016) where the average anxiety level in the experimental group (22.46) is lower than the average anxiety level in the control group (41.54), thus, psychoeducation is effective in reducing anxiety levels in CHD patients (22)

\section{Conclusion}

Based on the results of the study, it can be concluded that most (58.1\%) of the respondents are male, aged 50-66 years on average, have moderate levels of anxiety $(61.3 \%)$ before the intervention and no anxiety (83.9 \%) after intervention with the Guided Imagery relaxation technique and Health Education. Statistically, there are differences in anxiety levels in heart failure patients at Hospital X before and after the Guided Imagery relaxation technique and Health Education (Pvalue $=0.000)$. These results demonstrate that guided imagery therapy and health education can be an alternative non-pharmacological therapy to reduce anxiety levels in heart failure patients. The results can be applied by the respondents continuously to reduce the anxiety level of heart failure patients without any side effects such as those caused by pharmacological therapies.

\section{Acknowledgments}

STIK Sint Carolus Jakarta, Head of the Faculty of Health Sciences at the Universitas Nasional, Head of the Nursing and Professional Nursing Study Program and Director of the Cinere Diagram Heart Hospital, Depok.

\section{References}

1. Darma Putra PB, Purwaningsih P. Manajemen Perawatan Diri Pada Klien Gagal Jantung Pendekatan Systematic Review: Universitas Ngudi Waluyo; 2021.

2. Ambrosy AP, Fonarow GC, Butler J, Chioncel O, Greene SJ, Vaduganathan M, et al. The global health and economic burden of hospitalizations for heart failure: lessons learned from hospitalized heart failure registries. Journal of the American College of Cardiology. 2014;63(12):1123-33.

3. Nurmasani A, Pristyanto Y. Algoritme Stacking Untuk Klasifikasi Penyakit Jantung Pada Dataset Imbalanced Class. Pseudocode. 2021;8(1):21-6.

4. Celano CM, Villegas AC, Albanese AM, Gaggin HK, Huffman JC. Depression and anxiety in heart failure: a review. Harvard review of psychiatry. 2018;26(4):175.

5. Chauvet-Gelinier J-C, Bonin B. Stress, anxiety and depression in heart disease patients: A major challenge for cardiac rehabilitation. Annals of physical and rehabilitation medicine. 2017;60(1):612.

6. Chen S-F, Wang H-H, Yang H-Y, Chung U-L. Effect of relaxation with guided imagery on the physical and psychological symptoms of breast cancer patients undergoing chemotherapy. Iranian Red Crescent Medical Journal. 2015;17(11).

7. Laksmi IAA, Putra PWK. Studi korelasi antara BMI dengan mortalitas pasien gagal jantung kongestif. Gaster. 2019;17(1):11-9.

8. Dunlay SM, Roger VL, Redfield MM. Epidemiology of heart failure with preserved ejection fraction. Nature Reviews Cardiology. 2017;14(10):591-602. 
9. Mardiani N, Hermawan B. Pengaruh Teknik Distraksi Guidance Imagery Terhadap Tingkatan Ansietas Pada Pasien Pra Bedah Di Rsud Linggajati Kabupaten Kuningan. Jurnal Soshum Insentif. 2019:136-44.

10. Edmealem A, Olis CS. Factors associated with anxiety and depression among diabetes, hypertension, and heart failure patients at Dessie Referral Hospital, Northeast Ethiopia. Behavioural Neurology. 2020;2020.

11. Ainunnisa K, Hudiyawati D. Hubungan Antara Jenis Kelamin dengan Tingkat Kecemasan Pada Pasien Gagal Jantung: Universitas Muhammadiyah Surakarta; 2020.

12. Easton K, Coventry P, Lovell K, Carter L-A, Deaton C. Prevalence and measurement of anxiety in samples of patients with heart failure: meta-analysis. The Journal of cardiovascular nursing. 2016;31(4):367.

13. Haris DE, Rampengan SH, Jim EL. Gambaran pasien gagal jantung akut yang menjalani rawat inap di RSUP Prof Dr. RD Kandou periode September-November 2016. e-CliniC. 2016;4(2).

14. Wati ZME, Oktarina Y, Rudini D. Hubungan Tingkat Kecemasan Dengan Kualitas Tidur Pada Pasien Gagal Jantung Kongestif (CHF). Jurnal Ilmiah Ners Indonesia. 2020;1(1):46-57.

15. Sankaranarayanan R, Hartshorne-Evans N, Redmond-Lyon S, Wilson J, Essa H, Gray A, et al. The impact of COVID-19 on the management of heart failure: a United Kingdom patient questionnaire study. ESC heart failure. 2021;8(2):1324-32.

16. Tajudin T, Nugroho IDW. Analisis Kombinasi Penggunaan Obat Pada Pasien Jantung Koroner (Coronary Heart Disease) Dengan Penyakit Penyerta Di Rumah Sakit X Cilacap Tahun 2019. Pharmaqueous: Jurnal Ilmiah Kefarmasian. 2020;1(2):6-13.

17. Djunaidi A, Indrawan B. Hubungan Usia dan Merokok pada Penderita Penyakit Jantung Koroner di Poli Penyakit Dalam RS MHPalembang Periode Tahun 2012. Syifa'MEDIKA: Jurnal Kedokteran dan Kesehatan. 2014;5(1):16-26.

18. Purnama I, Gan WL, Wong DW, Lew WS. Guided current-induced skyrmion motion in 1D potential well. Scientific reports. 2015;5(1):1-9.

19. Febtrina R, Febriana W. Teknik Relaksasi Imajinasi Terbimbing (Guided Imagery) Menurunkan Nyeri Pasien Pasca Serangan Jantung [Guided Imagination Relaxation Techniques Reduce Patient's Pain Post Attack Heart]. Nursing Current: Jurnal Keperawatan. 2019;5(2):41-9.

20. Esmaeili Vardanjani SA, Fanisaberi L, Alirezaee Shahraki F, Khalilzadeh A, Tavakoli Vardanjani A, Ghani Dehkordi F. The effect of face-to-face education and educational booklet on heart health indexes of the hospitalized patients with myocardial infarction. Nursing research and practice. 2013;2013.

21. Yancy CW, Jessup M, Bozkurt B, Butler J, Casey Jr DE, Drazner MH, et al. 2013 ACCF/AHA guideline for the management of heart failure: executive summary: a report of the American College of Cardiology Foundation/American Heart Association Task Force on practice guidelines. Circulation. 2013;128(16):1810-52.

22. Easton K, Carter A, Lovell K, Deaton C, Coventry P. The prevalence and variance of anxiety in patients with a diagnosis of heart failure: Meta-analysis. The Journal of Cardiovascular Nursing. 2015. 